\title{
Characterization of the Dominant Bacterial Communities Associated with Terrestrial Isopod Species Based on 16S rDNA Analysis by PCR-DGGE
}

\author{
Delhoumi Majed, Zaabar Wahiba, Bouslama Mohamed Fadhel, Achouri Mohamed Sghaier* \\ Laboratory of Bio-Ecology and Evolutionary Systematics, Department of Biology, Faculty of Sciences of Tunis, \\ University of Tunis El Manar, Tunis, Tunisia \\ Email: delhoumimajed@gmail.com, zaabarwahiba@gmail.com, hatem.bouslama@gmail.com, \\ *mohamed.achouri@gmail.com
}

How to cite this paper: Majed, D., Wahiba, Z., Fadhel, B.M. and Sghaier, A.M. (2018) Characterization of the Dominant Bacterial Communities Associated with Terrestrial Isopod Species Based on 16S rDNA Analysis by PCR-DGGE. Open Journal of Ecology, 8, 495-509.

https://doi.org/10.4236/oje.2018.89030

Received: January 30, 2018

Accepted: September 15, 2018

Published: September 18, 2018

Copyright (c) 2018 by authors and Scientific Research Publishing Inc. This work is licensed under the Creative Commons Attribution International License (CC BY 4.0).

http://creativecommons.org/licenses/by/4.0/

\begin{abstract}
From the marine environment, woodlice gradually colonized terrestrial areas benefiting from the symbiotic relationship with the bacterial community that they host. Indeed, they constitute the only group of Oniscidea suborder that has succeed to accomplish their lives in terrestrial even desert surfaces. Herein they play an important role in the dynamic of ecosystems and the decomposition of litter. So to enhance our understanding of the sea-land transition and other process like decomposition and digestion of detritus, we studied the bacterial community associated with 11 specimens of terrestrial isopods belonging to six species using a Culture independent approach (DGGE). Bands sequencing showed that the cosmopolitan species Porcellionides pruinosus has the most microbial diversity. Screening demonstrated the predominance of Proteobacteria followed by members from Actinobacteria, Firmicutes and Cyanobacteria phyla. In fact we detected some symbionts like Wolbachia, Mycoplasma and Spiroplasma for the first time in a terrestrial isopod species.
\end{abstract}

\section{Keywords}

Microbial Community, PCR-DGGE, Terrestrial Isopod, Symbiont

\section{Introduction}

Woodlice are considered as important decomposers of leaf litter. Therefore, these soil detritivores contribute mainly to the ecosystem function by mineraliz- 
ing organic matter [1] or through transforming litter into fecal pellets characterized by a simple and rapid decomposition. It has been shown that Oniscidea exploit than $10 \%$ of the annual litter increasing fourfold the surface available to microorganisms [2]. Moreover, terrestrial isopods constitute a source of calcium and can thus serve as a reservoir for heavy metals like lead, copper, zinc [3] and mercury [4] [5].

From an aquatic environment, terrestrial isopods gradually invaded terrestrial areas taking profit from the symbiotic relationship with microorganisms. Bacterial symbionts allow their host to spread and to occupy unfilled niches [6] [7]. Therefore, Oniscidean isopods are the only one of ten isopod suborders where the majority of species have become independent of the aquatic environment. In this sense, it has been evidenced that arthropods such as isopods are known to house a wide range of bacteria that can affect the biology of their host by the manipulation of reproduction (as the bacteria Wolbachia) [8], locomotion [9], diet [10] and interspecific competition [11]. On the other hand, [12] established that microbes can cause profound effects on the nutritional ecology, defensive interactions, reproduction, development and genome evolution of their hosts. Symbionts are found in multiple compartments within Oniscidea. Indeed they colonize the genital tract, the head, the abdominal cavity, the cytoplasm and the digestive tissues.

Isopods are widespread in marine, intertidal and terrestrial habitats [6] and this may partly due to the advantages provided by the bacterial partner. In fact, nutritional symbiote improves the digestion process by hydrolysis of cellulose and the oxidation of phenol and lignin via the enzymatic activity within the arthropod gut [13] [14]. Besides, microbial activity permits the providing of essential nutrients such as amino acids and vitamins [15].

Simultaneously, bacteria colonizing the hepatopancreas contribute to the secretion of digestive enzymes and the absorption of nutrients [16] [17]. Given the lack of baseline information on the dynamics of microbial flora associated with terrestrial isopods [18] and the focusing interest primarily on the presence of Wolbachia infections in Oniscidea [19], it is of importance to deepening our knowledge concerning the total microbial communities associated with terrestrial isopod species. Hence terrestrial isopods provide an excellent model to study the evolutionary transition from sea to land from an adaptive point of view.

To get a first impression on the microbial community associated oniscidean species we used a molecular approach. Indeed, the culture-independent fingerprinting technique DGGE was used to accomplish such purpose. DGGE analysis has been used to monitor changes in the microbial community associated environmental samples [20]. This molecular tool allows to separate DNA fragments that are identical in length based on their melting characteristics in a gradient of chemical denaturant [21].

The aim of this study is to screen the microbial community associated with a 
set of terrestrial isopods species using a molecular approach. Therefore, we examine the impact of the host species on the microbial community shaping.

\section{Materials and Methods}

\subsection{Sampling}

Sampling was carried out during spring 2013 from 9 localities in Tunisia (Figure 1). Specimens were collected manually from soil, plants, under rocks and bark of trees. Six species of terrestrial isopod were identified using a binocular microscope (Leica MS 5) and the works of Hamaied (2008) [22] and Vandel (1960) [23] and Vandel (1962) [24] (Table 1).

\subsection{Extraction of Total DNA}

Samples were rinsed with ethanol and twice with distilled water in order to avoid

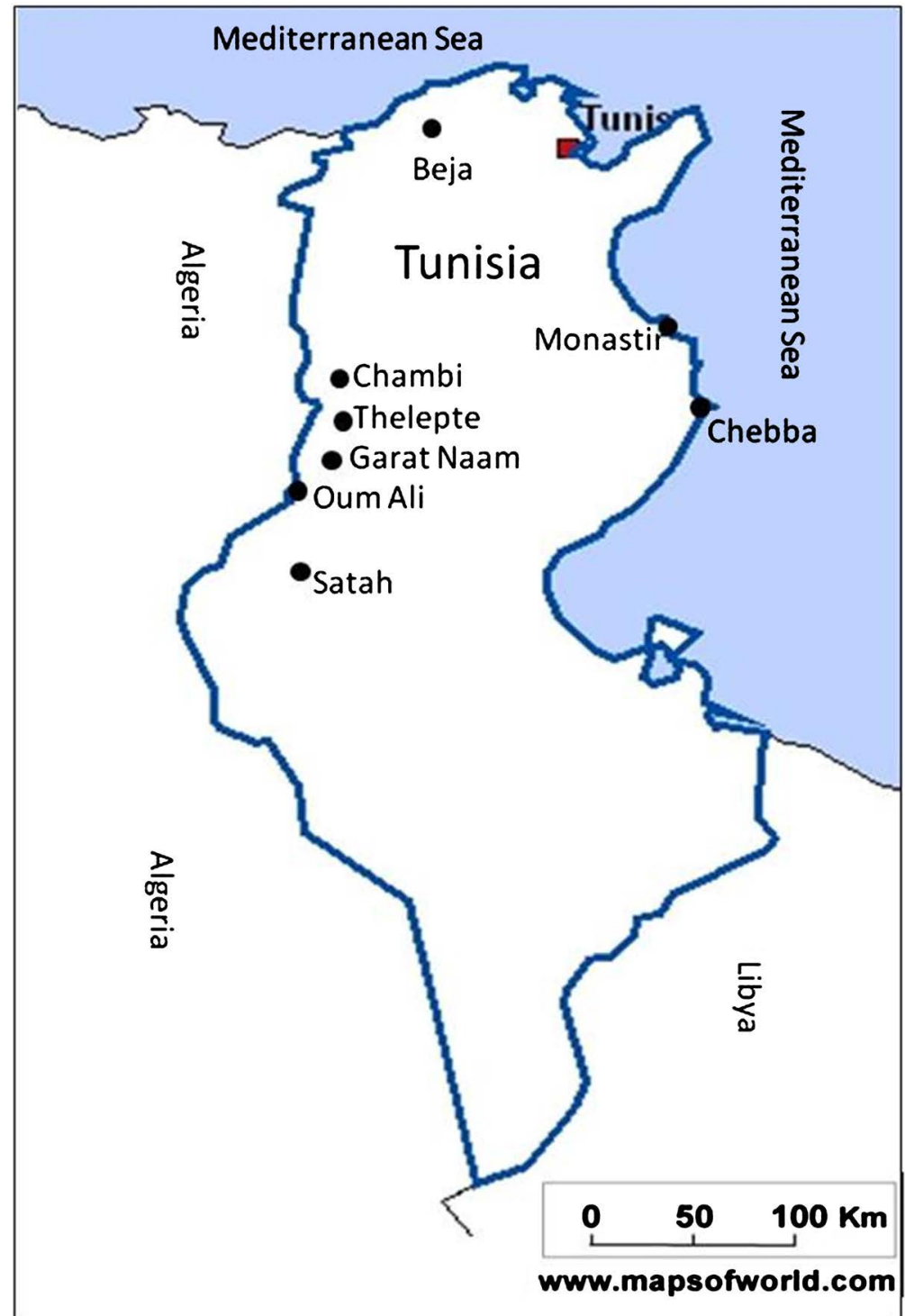

Figure 1. Sampling sites of terrestrial isopod species from Tunisia. 
Table 1. Result of sequencing bands.

\begin{tabular}{|c|c|c|c|c|c|}
\hline $\begin{array}{l}\text { Isopod } \\
\text { species }\end{array}$ & $\begin{array}{l}\text { Sampling } \\
\text { site }\end{array}$ & $\begin{array}{l}\text { DGGE } \\
\text { bands }\end{array}$ & Closest related sequence & Id.\% & Acc. No \\
\hline P. laevis & Chebba & $\mathrm{B} 20$ & Paracoccus saliphilus & $90 \%$ & NR_044021 \\
\hline L. panzerii & G. Naam1 & B19 & Saccharopolyspora flava & $76 \%$ & NR_028754 \\
\hline L. panzerii & Monastir & B17 & Sinorhizobium medicae & $97 \%$ & NR_074254 \\
\hline P. laevis & Chambi & B23 & $\begin{array}{l}\text { Wolbachia endosymbiont of } \\
\text { Culex quinquefasciatus Pel }\end{array}$ & $82 \%$ & NR_074127 \\
\hline P. pruinosus & Tunis & B15 & Paracoccus bengalensis & $97 \%$ & NR_042359 \\
\hline L. panzerii & G. Naam2 & B14 & Spiroplasma montanense & $86 \%$ & NR_025709 \\
\hline A. officinalis & Chebba & B13 & Paracoccus fistulariae & $83 \%$ & NR_104533 \\
\hline \multirow{2}{*}{ A. officinalis } & \multirow{2}{*}{ Beja } & B11 & Pseudochrobactrum lubricantis & $93 \%$ & NR_104538 \\
\hline & & B12 & Pseudochrobactrum lubricantis & $98 \%$ & NR_104538 \\
\hline \multirow{7}{*}{ P. pruinosus } & \multirow{7}{*}{ Thelepte } & B6 & Calothrix sp. & $88 \%$ & NR_102891 \\
\hline & & B7 & Cellulomonas denverensis & $80 \%$ & NR_042936 \\
\hline & & B8 & Kineococcus xinjiangensis & $90 \%$ & NR_044522 \\
\hline & & B9 & Georgenia muralis & $89 \%$ & NR_026305 \\
\hline & & $\mathrm{B} 10$ & Isoptericola hypogeus & $94 \%$ & NR_042355 \\
\hline & & B21 & $\begin{array}{l}\text { Wolbachia endosymbiont of } \\
\text { Culex quinquefasciatus Pel }\end{array}$ & $82 \%$ & NR_074127 \\
\hline & & B22 & $\begin{array}{l}\text { Wolbachia endosymbiont of } \\
\text { Culex quinquefasciatus Pel }\end{array}$ & $82 \%$ & NR_074127 \\
\hline \multirow{2}{*}{ H. reaumurii } & \multirow{2}{*}{ Satah } & B3 & Paracoccus saliphilus & $96 \%$ & NR_044021 \\
\hline & & B4 & Niabella ginsengisoli & $84 \%$ & NR_044541 \\
\hline A. tunisiense & Oum Ali & B2 & Mycoplasma cynos & $83 \%$ & NR_102477 \\
\hline
\end{tabular}

contamination. DNA was extracted from the whole animal using a commercial kit (Abiopure Alliance) according to the manufacturer's procedure. DNA quality was determined using the NanoDrop ND-1000 spectrophotometer (NanoDrop Technologies) and stored at $-20^{\circ} \mathrm{C}$.

\subsection{Culture-Independent Approach: DGGE Analysis}

DGGE culture independent method allows the separation of amplified fragments that have the same molecular weight but with a different fusion temperature. PCR amplification of the bacterial 16S rDNA gene was performed using the primers 907R CCGTCAATTCCTTTGAG TTT and 357F TACGGGAGGCAGC AG [25]. The amplified sequences correspond to the V3-V5 hypervariable region of the $16 \mathrm{~S}$ rDNA gene. A $40 \mathrm{bp}$ GC clamp was added to primer 357F to avoid complete denaturing and separation of the DNA strands while migrating in denaturant conditions [21]. PCR products were resolved on $7 \%(\mathrm{w} / \mathrm{v})$ polyacryla- 
mide gel in $1 \times$ TAE pH 7.4 using a denaturing gradient, which ranged from $40 \%$ to $60 \%$. Gels were run at $99 \mathrm{~V}$ for 17 hours at $60^{\circ} \mathrm{C}$.

After electrophoresis, the gel was stained for $30 \mathrm{~min}$ in ethidium bromide solution, washed with sterile distilled water and photographed on a UV transillumination table. Dominant DGGE bands were excised and eluted by overnight incubation (12 hours) in $80 \mu \mathrm{l}$ of sterilized distilled water at $37^{\circ} \mathrm{C}$ with gentle shaking. The eluted DNA fragments were reamplified using unclamped 907R and $357 \mathrm{~F}$ primers, sequenced and deposited in the GenBank database. The DGGE band profiles were analyzed with an image analyzing system Image J software (version 1.46). PCA and CAH analysis were performed with free version of XLSTAT 752 software.

\section{Results and Discussion}

\subsection{Bacterial Diversity in Terrestrial Isopods}

11 from 14 examined amplicons of the 16S rRNA fragments gave a positive result; Armadillidium tunisiense (Oum Ali), Porcellionides pruinosus (Thelepte), Hemilepistus reaumurii (Satah), Armadillo officinalis (Beja), Armadillo officinalis (Chebba), Porcellionides pruinosus (Tunis), Porcellio laevis (Chambi), Leptothricus panzerii (Monastir), Leptotrichus panzerii (Garat Naam1 and 2) and Porcellio laevis (Chebba) (Figure 2).

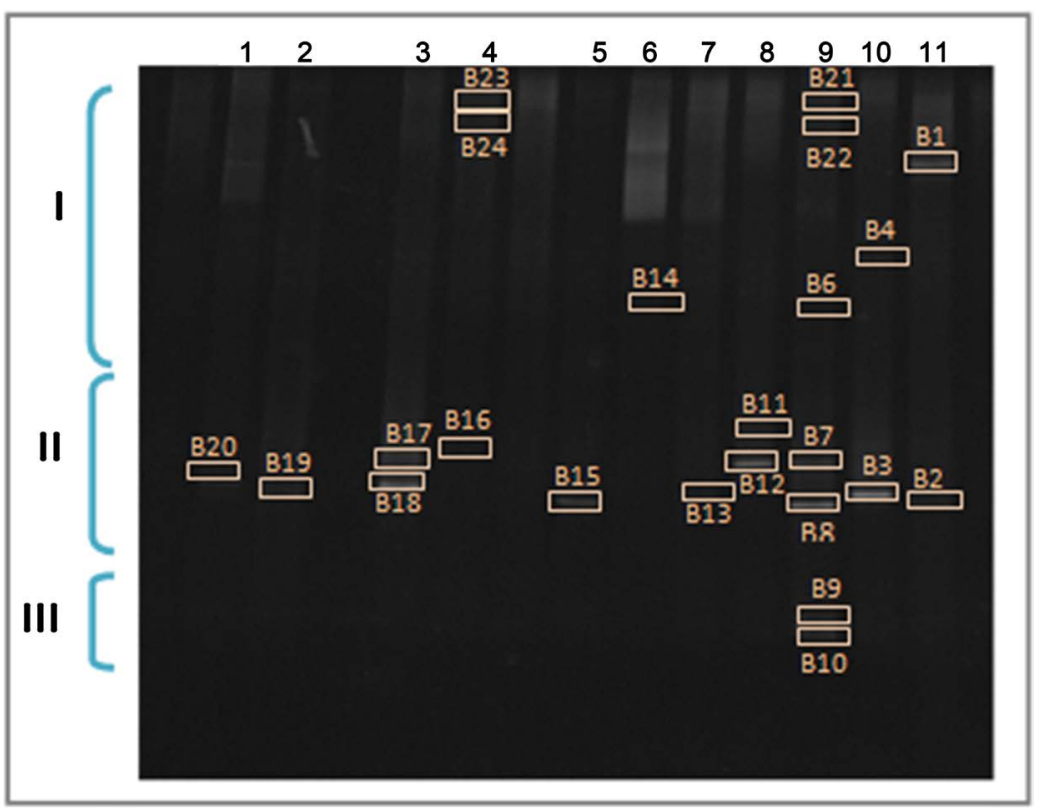

Figure 2. DGGE profile of the bacterial community associated with terrestrial isopods samples according to V3 region variability. Short (I), medium (II) and long migration (III); (1) Porcellio laevis (Chebba), (2) Leptotrichus panzerii (Garat Naam 1), (3) Leptothricus panzerii (Monastir), (4) Porcellio laevis (Chambi), (5) Porcellionides pruinosus (Tunis), (6) Leptotrichus panzerii (Garat Naam 2), (7) Armadillo officinalis (Chebba), (8) Armadillo officinalis (Beja), (9) Porcellionides pruinosus (Thelepte ), (10) Hemilepistus reaumurii (Satah) and (11) Armadillidium tunisiense (Oum Ali). 
The most complex profiles correspond to the samples 9 and 4 relating to $P$. pruinosus and $P$. laevis from Thelepte and Chambi respectively and secondly those of the samples 3, 8, 10 and 11 relating to $L$. panzerii (Monastir), A. officinalis (Beja), $H$. reaumurii from Satah and $A$. tunisiense sampled from Oum Ali.

In fact, the profiles complexity reflects the microbial flora diversity. It depends on species and its local environment. Similarly, it has been shown that the microbial flora structure is closely linked to the host species and its geographical location [26].

The most common bands (21, 22 and 23) had a resemblance of sequences with Wolbachia. The bands 3, 13, 15 and 20 exhibited a homology with members from the bacterial genera Paracoccus. This bacterium was detected in the majority of individuals examined. It is interesting to point out that this technique can detect only $1-2 \%$ of microbial communities that represent the dominant species. Besides, bacterial symbionts are not easily detectable in arthropods [27].

A total of 24 DGGE bands predominant were excised from the gel to be amplified and sequenced. The sequences obtained were identified by comparison with those available in the gene bank using the BLAST (Basic Local Alignment Search Tool) software (Table 1).

\subsection{Sequencing of Bands}

The sequencing of the reamplified band revealed the presence of four taxonomic groups of bacteria with a difference of dominance (Figure 3). Indeed profiling gave $42 \%$ of Proteobacteria (bands 3, 4, 11, 12, 13, 15, 17, 21, 22 and 23), 35\% of Actinobacteria (bands 7, 8, 9, 10 and 19), 14\% of Mollicutes (bands 2 and 14) and $8 \%$ of Cyanobacteria through the strip 6. Otherwise, Lapanje et al. 2010 [28] showed that Actinobacteria is one of the most detected isolated phyla from the gut of Porcellio scaber originating from a polluted area. Hence it has been suggested that this class is involved in the physiological resilience of the cited species. It has been mentioned that representatives of Actinobacteria have a crucial role in improving the quality of nutrients poor in nitrogen within the Onicidean

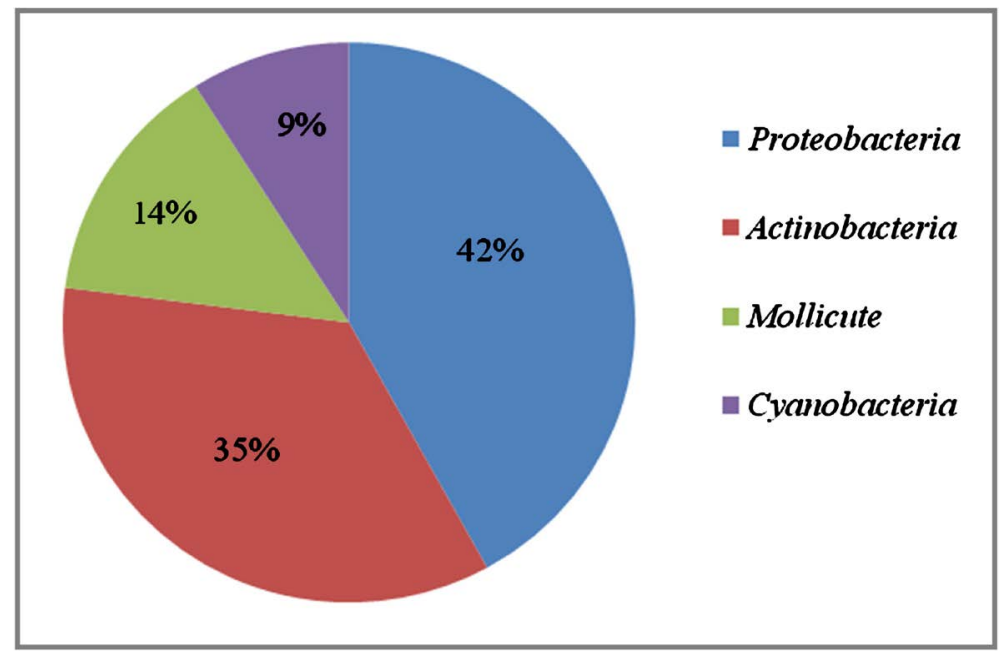

Figure 3. Percentage representation of bacterial phyla in studied isopods. 
species $P$. scaber. In the same line Actinobacteria was the most second group detected in the gut of $A$. vulgare [26].

Sequencing revealed the presence of common bands across screened specimens. Wolbachia was detected in P. pruinosus (bands 21 and 22) and P. laevis from Chambi (band 23) In fact, the first species showed the most complex profile represented by Calothrix sp, Cellulomonas deverensis, Kineococcus xinjiangensis, Georgenia muralis and Isoptericola hypogeus apart from Wolbachia. Bands 3, 13, 20 and 15, correspond to bacteria from the genus Paracoccus. Paracoccus saliphilus was common in P. laevis (Chebba) and H. reaumurii (Satah), Paracoccus bengalensis hosted by $P$. pruinosus from Tunis and Paracoccus fistulariae associated with $A$. officinalis from Chebba.

Bands 11 and 12 detected in Armadillo officinalis from Beja showed a significant homology of sequence with Pseudobachtrum lubricantis. Band 4 extracted from the DGGE profile of $H$. reaumurii (Satah) has a homology of sequences with Niabella ginsengisoli. Band 2 isolated from the species A. tunisiense (Oum Ali) is closely related to the symbiont Mycoplasma cynos. Saccharopolyspora flava and Spiroplasma montanense were detected in the two samples of L. panzerii from Garat Naam. Sinorhizobium medicae (band 17) was associated with $L$. panzerii from Monastir.

\subsection{Distribution of Bacterial Community Based on Species and Its Locality}

The principal component analysis (PCA) based on the variation of the bacterial community as function to the terrestrial isopod species showed a variation of $47.41 \%$ and $11.98 \%$ according to the axes F1 and F2 according to the species and locality (Figure 4).

We can distinguish three groups; the first is formed by the species $H$. reaumurii (Satah), A. officinalis (Chebba), P. pruinosus (Tunis) and P. laevis (Chebba) which are negatively correlated with the axis F2. In fact, this group is formed by host species sharing the association with the bacterial genus Paracoccus. The second group formed by the species $L$. panzerii originating from Garat Naam and Monastir, A. officinalis (Beja), P. laevis (Chambi) and A. tunisiense (Oum Ali). While the third group is totally different in a function of the positive values of the $\mathrm{F} 1$ axis which is limited to the species $P$. pruinosus (Thelepte) having a bacterial profile different to the remaining specimens and which is constituted mainly by bacteria from the Actinobacteria group.

The difference in microbial pattern between samples could be attributed to the impact of species habitat as reported in [26] and [29] which established that the diversity of intestinal microflora is a function of soil and local environment.

\subsection{Analysis HCA of Bacterial Diversity Based Terrestrial Isopods Species}

Data analysis of the bacterial diversity in terms of species of terrestrial isopod by hierarchical clustering (HCA) (Figure 5) reflects the structure of DGGE profiles. 


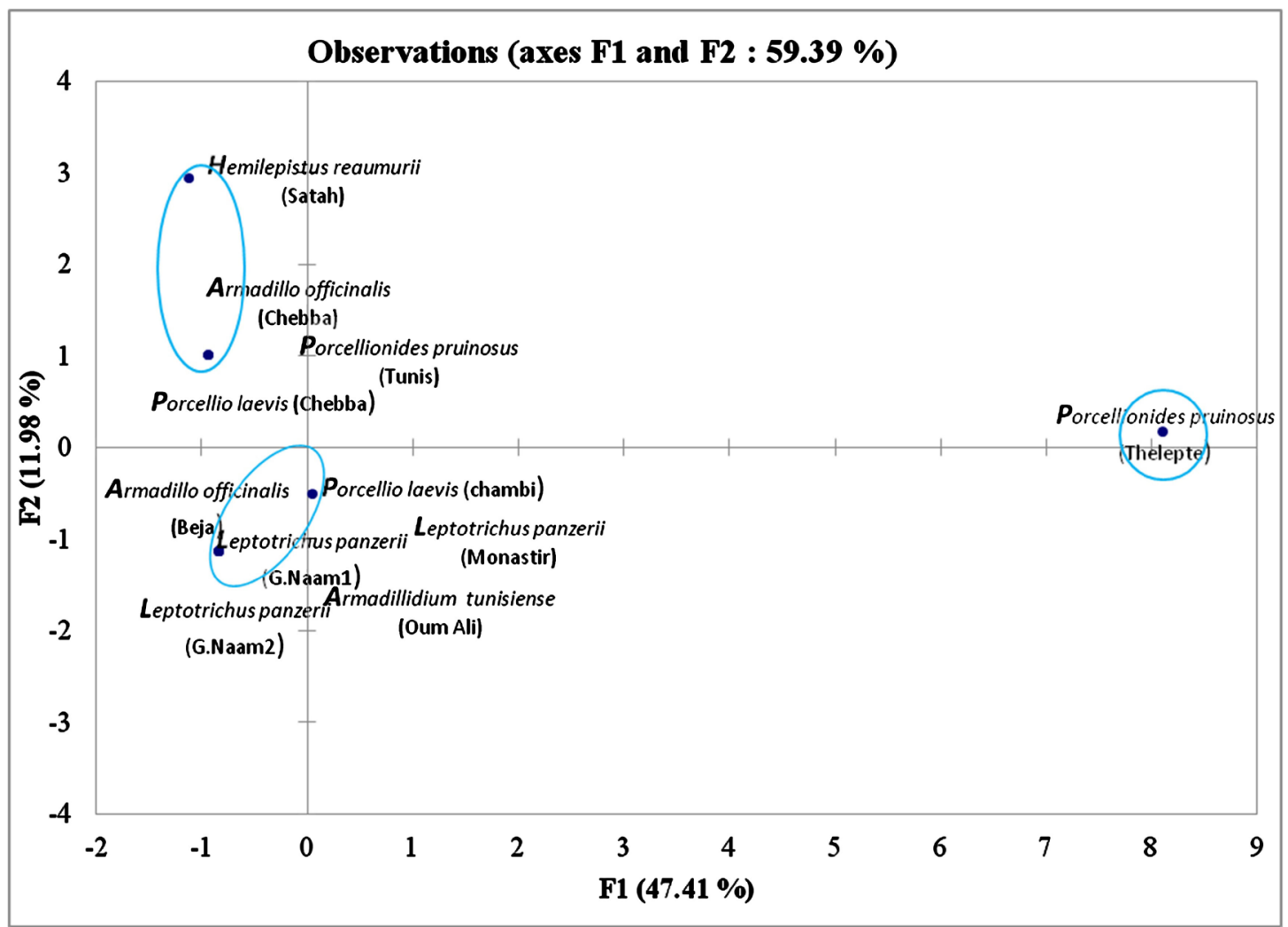

Figure 4. Principal component analysis of bacterial community as a function of the isopod species.

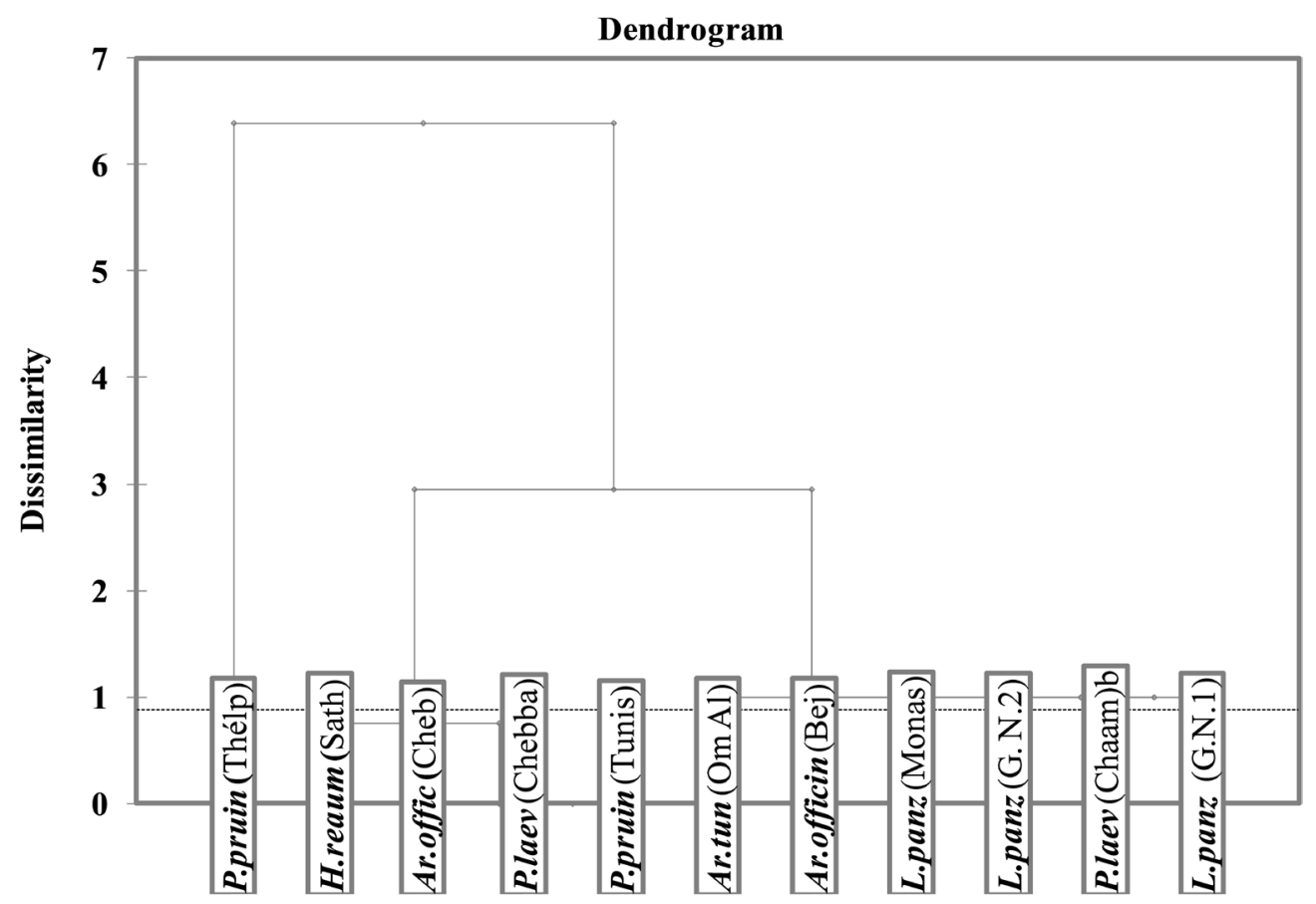

Figure 5. Analysis HCA of bacterial community based on Oniscidea species. Porcellionides pruinosus (Thelepte), Hemilepistus reaumurii (Satah), Armadillo officinalis (Chebba), Porcellio laevis (Chebba), Porcellionides pruinosus (Tunis) Armadillidium tunisiense (Oum Ali), Armadillo officinalis (Beja), Leptothricus panzerii (Monastir) Porcellio laevis (Chambi) Leptotrichus panzerii (Garat Naam 2) and Leptotrichus panzerii (Garat Naam 1). 
Indeed, a high level of dissimilarity separate $P$. pruinosus from Thelepte from the remaining species. Dissimilarity less marked, divide the rest of the samples into two groups, the first one is formed by the specie $H$. reaumurii (Satah), $A$. officinalis (Chebba), $P$. laevis (Chebba) and $P$. pruinosus from Tunis sharing the bacterial genus Paracoccus. The second group is formed by the species L. panzerii (Monastir) and (Garat Naam 1 and 2), P. laevis (Chambi), A. Tunisiense (Oum Ali) and $A$. officinalis (Beja) reflecting a mosaic of bacterial flora which might be acquired from the environment through ingested food.

\subsection{Detection of Wolbachia}

Three sequenced bands showed a homology with the famous bacteria Wolbachia. Indeed, it was detected in two different species; P. laevis and P. Pruinosus. These two species are known as the host for this bacterium in Tunisia [30] [31]. Wolbachia is an obligate intracellular bacterium affecting a wide range of arthropods including $60 \%$ of terrestrial isopods [32]. Wolbachia is a reproductive parasite that manipulates the reproduction of its host serving its own maternally transmission. It is responsible for a set of phenotypes including cytoplasmic incompatibility, male killing, thelytokous parthenogenesis and feminization of males [19]. In addition, [33] suggested that Wolbachia may confer several reproductive advantages like fertility and longevity in infected females for example in the species A. vulgare, the presence of Wolbachia enhances the immunocompetence by causing an increase in natural septicemia.

In our study, the estimated values of the sex ratio for both species harboring Wolbachia $P$. pruinosus from Thelepte and $P$. laevis from Chambi was strongly biased in favor of females (over 60\%) which raise the probability of feminizing activity of Wolbachia in these species.

\subsection{Detection of Spiroplasma}

The band (14) from DGGE profile of $L$. panzerii has a sequences homology to Spiroplasma montanense. This bacteria affects a wide range of arthropods, it can be symbiotic or pathogen [34]. Some species of Spiroplasma genus are vertically transmitted to the progeny. In some cases, Spiroplasma can modify the sex ratio by killing infected males then ultimately leading to an exclusively female population [35]. In fact, it has been shown that this bacterium shares with Wolbachia the induction of male killing during embryogenesis in Drosophila [36]. In arthropods, Spiroplasma can colonize the digestive system where it can play a role in the digestion process of the host and in the decomposition of plant material. In plants, this bacterium can be found on the surface, in particular flowers, and phloem.

The bacterial symbiotic of the genus Spiroplasma has long been associated with arthropods but never in isopods. In fact, [37] showed that this bacterium infects $6 \%$ and $23.1 \%$ of insects and spider respectively but until now no study has revealed an association relationship between Spiroplasma and terrestrial iso- 
pods. Thus, this study is the first to report it.

\subsection{Mycoplasma Detection}

The DGGE profile of the species $A$. officinalis showed a band which sequences are homologous to that of Mycoplasma symbiotic of arthropods. Indeed, it has been shown that this bacterium is endowed with a tissue specificity in arthropods especially among semi-terrestrial isopods like Ligia genus where it was associated with the hepatopancreas [38], as well as in the terrestrial isopod P. scaber [39]. Its presence is correlated with the surviving of terrestrial isopods exposed to a diet of poor quality for 90 days. Controversially, it acts negatively on longevity whatever the diet quality [17]. It has been shown that Mycoplasma is involved in the cellulose digestion and the oxidation of phenol. This symbiont of hepatopancreas can be acquired from the environment [40]. Apart from Wolbachia, the terrestrial isopod $P$. pruinosus has a diverse microbial community marked by soil microbes or plant symbionts that colonize the digestive tissues through digested nutrient. For example, the bacteria Calothrix sp. can be harbored by plants, algae, stones and wood substrates in wetland [41].

Since the gut constitutes the best suited exchange organ with the environment of terrestrial isopod [14], the microbial pattern in P. pruinosus reflects the environment of Thelepte characterized by a mountain area belonging to a semi-arid bioclimatic with cool winters. In addition, the diversity of microbial flora found in this species could explain its ecological plasticity and consequently the wide distribution. In this line, a metagenomic analysis of the digestive tissues of this species showed a great diversity of bacteria including hepatopancreatic symbionts, cellulolytic bacteria and reproductive parasites like Wolbachia and Serratia (Unpublished data). Indeed [26] showed that the host protection against fluctuation of environmental conditions and the resistance to environmental stress depend on the microbial flora diversity. Besides, the bacterial symbionts allow their host to spread and to occupy unfilled niches through the adaptive capabilities especially nutritive ones as shown by [7]. Therefore, symbionts diversity provide several advantages to the host like the genetic differentiation, the adaptation to a wide range of food plants and the sensitivity to thermal stress and other environmental factors [12] [42] [43]. It has been shown that the amount of biofilm colonizing the leaf litter affects the life history of the terrestrial isopod P. Scaber [44].

Cellulomonas is known as an aerobic microorganism which can be found in water and soil. It is capable to hydrolyze cellulose and produce a large quantity of enzymes degrading cellulose [45]. The genus Paracoccus is the most represented in the studied samples. Indeed four species are associated with this microorganism; $H$. reaumurii (Satah) and P. laevis (Chebba) harbor the same species, A. officinalis (Chebba) and $P$. pruinosus (Tunis).

In fact, Paracoccus bacteria are known as symbiotic for pulses food. They are associated with soil and plants where they allow the reduction of nitrate [46]. 
This bacterium was introduced as a bioindicator of pollution. Hence, [28] showed that this microorganism confers resistance to its host $P$. scaber against pollution. Paracoccus is the most common bacterial genus in individuals collected from the contaminated area. It has been proposed that it is responsible for the resistance of the terrestrial isopod species to pollutant. Consistently, the species harboring $\mathrm{Pa}$ racoccus were $P$. laevis and $A$. officinalis sampled from Chebba marked by a salt area and $H$. reaumurii collected from Satah characterized by phosphate mines.

Several bacteria detected in this study are simple passengers which are acquired from soil and plants through ingested nutrients and eliminated later through feces. Indeed, [47] showed a rapid elimination of non-indigenous pathogenic bacteria by scorpion after each meal.

Sequencing results reflect a mosaic of bacteria transmitted via a horizontal or vertical path and which are variable depending on the species and sampling sites. The most relevant example is the different bacterial profiles between $P$. pruinosus from Tunis and Thelepte. This finding corroborates previous studies showing that the bacterial prevalence varied greatly depending on environment even within the same species of terrestrial isopod [17] [26] [40].

\section{Conclusions}

The microbial community associated with a set of Oniscidean species was targeted based on $16 \mathrm{~S}$ rDNA-DGGE fingerprinting. 16S rDNA sequencing revealed that the microbial community was composed by members of Cyanobacteria, Actinobacteria, Protobacteria and Mollicutes. Furthermore, we detected the reproductive manipulator Wolbachia which is known to affect the whole biology, behavior and physiology of arthropods. Wolbachia has been previously studied in many species of terrestrial isopods in Tunisia like $P$. pruinosus, $A$. sulcatum, $P$. albinus and $P$. laevis. Mycoplasma was reported scarcely in some species like $P$. scaber. Finally Spiroplasma that is present has never been demonstrated previously within terrestrial isopods.

Although other microbes were detected, their role remains elusive. It is quite possible that the presence of these bacteria is transient rather than permanent. Further studies are needed to determine their interaction with the host species.

\section{Acknowledgements}

The authors would like to thank Professor Maher Gtari from the Laboratory of Microorganisms and Active Biomolecules and to those who contributed to the field and laboratory components of this work. This work was undertaken within the framework of the research activities of the laboratory of "Bio-Ecology and Evolutionary Systematics" financed by the Tunisian Ministry of Higher Education, Scientific Research.

\section{Conflicts of Interest}

The authors declare no conflicts of interest regarding the publication of this paper. 


\section{References}

[1] Hurst, G.D. and Jiggins, F.M. (2000) Male-Killing Bacteria in Insects: Mechanisms, Incidence, and Implications. Emerging Infectious Diseases, 6, 329-336. https://doi.org/10.3201/eid0604.000402

[2] Jambu, P., Juchault, P. and Mocquard, J.P. (1987) Experimental Study of the Contribution of the Isopod Crustacean Oniscus asellus to the Transformation of Forest Litter under Sessile Oak. Pedobiologia, 32, 147-156.

[3] Prosi, F. and Dallinger, R. (1988) Heavy Metals in the Terrestrial Isopod Porcellio scaber Latreille. I. Histochemical and Ultrastructural Characterization of Metal-Containing. Cell Biology and Toxicology, 4, 81-96. https://doi.org/10.1007/BF00141288

[4] Lapanje, A., Rupnik, M. and Drobne, D. (2007) Gut Bacterial Community Structure (Porcellio scaber, Isopoda, Crustacea) as a Measure of Community Level Response to Long-Term and Short-Term Metal Pollution. Environmental Toxicology and Chemistry, 26, 755-763. https://doi.org/10.1897/06-099R.1

[5] Lapanje, A., Drobne, D., Nolde, N., Valant, J., Muscet, B., Leser, V. and Rupnik, M. (2008) Long-Term Hg Pollution Induced Hg Tolerance in the Terrestrial Isopod Porcellio scaber (Isopoda, Crustacea). Environmental Pollution, 153, 537-547. https://doi.org/10.1016/j.envpol.2007.09.016

[6] Edney, E.B. (1968) Transition from Water to Land in Isopod Crustaceans. American Zoologist, 8, 309-326. https://doi.org/10.1093/icb/8.3.309

[7] Douglas, A.E. (1994) Symbiotic Interactions, Vol. Oxford University Press, Oxford.

[8] Stouthamer, R., Breeuwer, J.A. and Hurst, G.D. (1999) Wolbachia pipientis. Microbial Manipulator of Arthropod Reproduction. Annual Review of Microbiology, 53, 71-102. https://doi.org/10.1146/annurev.micro.53.1.71

[9] Fleury, F., Vavre, F., Ris, N., Fouillet, P. and Bouletreau, M. (2000) Physiological Cost Induced by the Maternally-Transmitted Endosymbiont Wolbachia in the Drosophila Parasitoid Leptopilina heterotoma. Parasitology, 121, 493-500. https://doi.org/10.1017/S0031182099006599

[10] Nakamura, Y., Kawai, S., Yukuhiro, F., Ito, S., Gotoh, T., Kisimoto, R., Yanase, T., Matsumoto, Y., Kageyama, D. and Noda, H. (2009) Prevalence of Cardinium Bacteria in Planthoppers and Spider Mites and Taxonomic Revision of "Candidatus Cardinium hertigii” Based on Detection of a New Cardinium Group from Biting Midges. Applied Environmental Microbiology, 75, 6757-6763. https://doi.org/10.1128/AEM.01583-09

[11] Sicard, M., Hinsinger, J., Le Brun, N., Pages, S., Boemare, N.E. and Moulia, C. (2006) Inter-Specific Competition between Entomopathogenic Nematodes (Steinernema) Is Modified by Their Bacterial Symbionts (Xenorhabdus). BMC Evolutionary Biology, 6, 68. https://doi.org/10.1186/1471-2148-6-68

[12] Charlat, S., Duplouy, A., Hornett, E.A., Dyson, E.A. and Davies, N. (2009) The Joint Evolutionary Histories of Wolbachia and Mitochondria in Hypolimnas bolina. BMC Evolutionary Biology, 9, 64. https://doi.org/10.1186/1471-2148-9-64

[13] Zimmer, M. and Topp, W. (1998) Microorganisms and Cellulose Digestion in the Gut of the Woodlouse Porcellio scaber. Chemistry and Ecology, 24, 1397-1408. https://doi.org/10.1023/A:1021235001949

[14] Zimmer, M., Danko, J.P. and Pennings, S.C. (2002) Cellulose Digestion and Phenol Oxidation in Coastal Isopods (Crustacea: Isopoda). Marine Biology, 140, 1207-1213. https://doi.org/10.1007/s00227-002-0800-2 
[15] Chandler, S.M., Wilkinson, T.L. and Douglas, A.E. (2008) Impact of Plant Nutrients on the Relationship between a Herbivorous Insect and Its Symbiotic Bacteria. Biological Science, 275, 565-570. https://doi.org/10.1098/rspb.2007.1478

[16] Hopkin, S.P. and Martin, M.H. (1982) The Distribution of Zinc, Cadmium, Lead and Copper within the Woodlouse Oniscus asellus (Crustacea, Isopoda). Oecologia, 54, 227-232. https://doi.org/10.1007/BF00378396

[17] Fraune, S. and Zimmer, M. (2008) Specificity of the Host Environment Transmitted Mycoplasma-Like Isopods Symbiotes. Environmental Microbiology, 10, 2497-2504. https://doi.org/10.1111/j.1462-2920.2008.01672.x

[18] Goffredi, S.K. (2011) Indigenous Ectosymbiotic Bacteria Associated with Diverse Hydrothermal Vent Invertebrates. Environmental Microbiology, 2, 479-488. https://doi.org/10.1111/j.1758-2229.2010.00136.x

[19] Cordaux, R., Paces-Fessy, M., Raimond, M., Michel-Salzat, A, Zimmer, M. and Bouchon, D. (2012) Molecular Characterization and Evolution of Arthropod-Pathogenic Rickettsiella Bacteria. Applied and Environmental Microbiology, 73, 5045-5047. https://doi.org/10.1128/AEM.00378-07

[20] Green, S.J., Leigh, M.B. and Neufeld, J.D. (2010) Denaturing Gradient Gel Electrophoresis (DGGE) for Microbial Community Analysis. In: Timmis, K.N., Ed., Handbook of Hydrocarbon and Lipid Microbiology, Springer, Berlin, Heidelberg, 4137-4158. https://doi.org/10.1007/978-3-540-77587-4_323

[21] Muyzer, G., de Wall, E.C. and Uitterlinden, A.G. (1993) Profiling of Complex Microbial Populations by Denaturing Gradient Gel Electrophoresis Analysis of Polymerase Chain Reaction Amplified Genes Encoding for 16S rRNA. Applied and Environment Microbiology, 59, 695-700.

[22] Hamaied-Melki, S. (2008) Systematic, Geographical Repartition and Eco-Biology of the Genus Armadillidium (Brandt, 1833) in Tunisia. Thesis Manuscript, Faculty of Sciences of Tunis, 1-211.

[23] Vandel, A. (1960) Terrestrial Isopods, 1. Fauna of France, Paris.

[24] Vandel, A. (1962) Terrestrial Isopods, 2. Fauna of France, Paris.

[25] Sass, A.M., Sass, H., Coolen, M.J., Cypionka, H. and Overmann, J. (2001) Microbial Communities in the Chemocline of a Hypersaline. Deep-Sea Basin (Urania Basin, Mediterranean Sea). Applied and Environmental Microbiology, 67, 5392-5402. https://doi.org/10.1128/AEM.67.12.5392-5402.2001

[26] Dittmer, J., Lesobre, J., Moumen, B. and Bouchon, D. (2016) Host Origin and Tissue Microhabitat Shaping the Microbiota of the Terrestrial Isopod Armadillidium vulgare. FEMS Microbiol Ecology, 92, fiw063.

https://doi.org/10.1093/femsec/fiw063

[27] Arthofer, W., Riegler, M., Avtzis, D.N. and Stauffer, C. (2009) Evidence of Low Infections and Insect Symbiosis: Wolbachia in the Bark Beetle Pityogenes chalcographus (Coleoptera, Scolytinae). Environmental Microbiology, 11, 1923-1933. https://doi.org/10.1111/j.1462-2920.2009.01914.X

[28] Lapanje, A., Zrimec, A., Drobne, D. and Rupnik, M. (2010) Long-Term Hg Pollution-Induced Structural Shifts of Bacterial Community in the Terrestrial Isopod (Porcellio scaber) Gut. Environmental Pollution, 158, 3186-3193. https://doi.org/10.1016/j.envpol.2010.07.001

[29] Bouchon, D., Zimmer, M. and Dittmer, J. (2016) The Terrestrial Isopod Microbiome: An All-in-One Toolbox for Animal-Microbe Interactions of Ecological Relevance. Frontiers in Microbiology, 7, 1472. https://doi.org/10.3389/fmicb.2016.01472 
[30] Ben Nasr, S., Gtari, M. And Azzouna, A. (2010) Detection and Phylogeny of the Bacteria Wolbachia in the Terrestrial Isopod Porcellio laevis Latr. (Crustacea, Oniscoidea), Isolated from Lebna and Bizerte Stations Tunisia. Annals of Microbiology, 60, 43-50. https://doi.org/10.1007/s13213-009-0001-z

[31] Michel-Salzat, A., Cordaux, R. and Bouchon, D. (2001) Wolbachia Diversity in the Porcellionides pruinosus Complex of Species (Crustacea: Oniscidea): Evidence for Host-Dependent Patterns of Infection. Heredity, 87, 428-434. https://doi.org/10.1046/j.1365-2540.2001.00920.x

[32] Ben Afia Hatira, H., Charfi Cheikhrouha, F. and Bouchon, D. (2008) Preliminary Results on the Infection Status of Terrestrial Isopods in Tunisia by Bacteria of Wolbachia Genus. International Symposium on the Biology of Terrestrial Isopods, 7, 117-123.

[33] Dobson, S.L., Rattanadechakul, W. and Marsland, E.J. (2004) Fitness Advantage and Cytoplasmic Incompatibility in Wolbachia Single- and Superinfected Aedes albopictus. Heredity, 93, 135-142. https://doi.org/10.1038/sj.hdy.6800458

[34] Bove, J.M. (1997) Spiroplasmas. Infectious Agents of Plants, Arthropods and Vertebrates. Wiener Klinische Wochenschrift, 10, 604-612.

[35] Kageyama, D., Anbutsu, H., Shimada, M. and Fukatsu, T. (2007) Spiroplasma Infection Causes either Early or Late Male Killing in Drosophila, Depending on Maternal Host Age. Naturwissenschaften, 94, 333-337. https://doi.org/10.1007/s00114-006-0195-x

[36] Hurst, G.D., Johnson, A.P., Schulenburg, J.H. and Fuyama, Y. (2000) Male-Killing Wolbachia in Drosophila: A Temperature-Sensitive Trait with a Threshold Bacterial Density. Genetics, 156, 699-709.

[37] Russell, J., Funaro, C.F., Giraldo, Y.M., Goldman-Huertas, B., Suh, D., Kronauer, D.J., Moreau, C.S. and Pierce, N.E. (2012) A Veritable Menagerie of Heritable Bacteria from Ants, Butterflies, and beyond: Broad Molecular Surveys and a Systematic Review. PLoS ONE, 7, e51027. https://doi.org/10.1371/journal.pone.0051027

[38] Renate, E. (2010) Sea-Land Transitions in Isopods: Pattern of Symbiont Distribution in Two Species of Intertidal Isopods Ligia pallasii and Ligia occidentalis in the Eastern Pacific. Symbiosis, 51, 107-116. https://doi.org/10.1007/s13199-010-0057-3

[39] Razin, S. (2006) The Genus Mycoplasma and Related Genera (Class Mollicutes). The Prokaryotes, 4, 836-904. https://doi.org/10.1007/0-387-30744-3_29

[40] Wang, Y., Brune, J. and Zimmer, M. (2007) Bacterial Symbionts in the Hepatopancreas of Isopods: Diversity and Environmental Transmission. FEMS Microbiology Ecology, 61, 141-152. https://doi.org/10.1111/j.1574-6941.2007.00329.x

[41] Komárek, S., Koupil, J. and Lonská, V. (1992) Antimicrobial Activity of Composite Filling Materials. Sb Ved Pr Lek Fak Karlovy Univerzity Hradci Kralove Suppl Czech, 35, 243-252.

[42] Tsuchida, T., Koga, R. and Fukatsu, T. (2004) Host Plant Specialization Governed by Facultative Symbiont. Science, 303, 1989.

https://doi.org/10.1126/science.1094611

[43] Montllor, C.B., Maxmen, A. and Purcell, A.H. (2002) Facultative Bacterial Endosymbionts Benefit Pea Aphids Acyrthosiphon pisum under Heat Stress. Ecological Entomology, 27, 189-195. https://doi.org/10.1046/j.1365-2311.2002.00393.x

[44] Horváthová, T., Kozłowski, J. and Bauchinger, U. (2015) Growth Rate and Survival of Terrestrial Isopods Is Related to Possibility to Acquire Symbionts. European Journal of Soil Biology, 69, 52-56. https://doi.org/10.1016/j.ejsobi.2015.05.003 
[45] Ma, L., Yang, W., Meng, F., Ji, S., Xin, H. and Cao, B. (2015) Characterization of an Acidic Cellulase Produced by Bacillus subtilis BY-4 Isolated from Gastrointestinal Tract of Tibetan Pig. Journal of the Taiwan Institute of Chemical Engineers, 56, 67-72. https://doi.org/10.1016/j.jtice.2015.04.025

[46] John, P. and Whatley, F.R. (1975) Paracoccus denitrificans and the Evolutionary Origin of the Mitochondria. Nature, 254, 495-498. https://doi.org/10.1038/254495a0

[47] Morel, G. (1976) Host-Parasite Relationship in Buthus occitanus Scorpion Diseases. Comptes Rendus Col. Arachnologie Fr., Les Eyzies, 100-105. 